\title{
MULTIDRUG RESISTANCE (MDR) OF V. Parahaemolyticus
}

\section{Marlina}

\author{
Faculty of Pharmacy, University of Andalas \\ e-mail: marlina adly@yahoo.com
}

\begin{abstract}
A total of $97 \mathrm{~V}$. parahaemolyticus isolate from Padang were examined for their resistance to 15 antibiotics. $V$. parahaemolyticus isolated behaved as resistant to sulfamethoxazole (100\%), rifampin (95\%) and tetracycline (75\%) and sensitive to norfloxacin (96\%). Ampicillin still sensitive for $V$. parahaemolyticus isolated from human stools. All of isolates were sensitive to namely chloramphenicol and floroquinolones (ciprofloxacin and norfloxacin agents). RAPD-PCR profiling with three primers (OPAR3, OPAR4 and OPAR8) produced four major clusters (R1, R2, R3 and R4), 7 minor clusters (I, II, III, IV, V, VI and VII) and three single isolates.
\end{abstract}

Keywords: V. parahaemolyticus, $M D R, R A P D$

\section{REFERENCES}

1. D. Ottaviani, I. Bacchiocchi, L. Masini, F. Leoni, A. Carraturo, M. Giammarioli, and G. Sbaraglia, Antimicrobial susceptibility of potentially halophilic vibrios isolated from seafood, International Journal of Antimicrobial Agents 18: 135-140, (2001).

2. A. Cespedes, and E. Larson, Knowledge, attitude and practices regarding antibiotic use among Latinos in the United States: Review and Recommendations, American Journal of Infection Control 34: 495-502, (2006).

3. M. Lesmana, D. Subekti, C.H. Simanjuntak, P. Tjaniadi, J. R. Campbell, and B. A. Ofoyo, Vibrio parahaemolyticus associated with cholera-like diarrhea among patients in North Jakarta, Indonesia, Diagnostic Microbiology and Infectious Disease, 39: 71-75, (2001).

4. S. Lu, B. Liu, B. Zhou, And R. E. Levin, Incidence and Enumeration of Vibrio parahaemolyticus in Shellfish from two retail Sources and the Genetic Diversity of isolates as Determined by RAPD-PCR
Analysis, Food Biotechnology, 20: 193209, (2006).

5. M. Nishibuchi, Vibrio parahaemolyticus. In International handbook of foodborne pathogens, ed. M.D. Milliots and J. W. Bier, United States: Marcel Dekker, Inc. P, 2004, 237-252.

6. L. Poirel, M. R. Martinez, H. Mammeri, A. Liard, and P. Nordmann, Origin of Plasmid-Mediated Quinolone Resistance Determinant QnrA, Antimicrobial Agents and Chemotherapy, 49: 3523-3525, (2005).

7. S. Radu, N. Elhadi, Z. Hassan, G. Rusul, S. Lihan, N. Fifadara, Yuherman and E. Purwati, Characterization of Vibrio vulnificus isolated from cockles (Anadara granosa): antimicrobial resistance, plasmid profiles and random amplification of polymorphic DNA analysis, FEMS Microbiology Letters, 165: 139-143, (1998).

8. S. Radu, N. Ahmad, F. H. Ling, and A. Reezal, Prevalence and resistance to antibiotics for Aeromonas species from retail fish in Malaysia, International of Journal Food Microbiology, 81: 261-266, (2003). 
9. B. Sarkar, N. R. Chowdhury, G. B. Nair, M. Nishibuchi, S. Yamasaki, Y. Takeda, S. K. Gupta, S. K. Bhattacharya, and Ramamurthy, Molecular characterization of Vibrio parahaemolyticus of similar serovars isolated from sewage and clinical cases of diarrhea in Calcutta, India, World Journal of Microbiology and Biotechnology, 19: 771-776, (2003).

10. S. Schwarz, and E. Chaslus-Dancla, Use of antimicrobials in veterinary medicine and mechanisms of resistance, Veterinary Residue, 32: 201-225, (2001).

11. H. Sörum, and T.M. L'Abèe-Lund,. Antibiotic resistance in food-related bacteria - a result of interfering with the global web of bacterial genetics,
International Journal of Food Microbiology, 78: 43-56, (2002).

12. P. Tjaniadi, M. Lesmana, D. Subekti, N. Machpud, S. Komalarini, W. Santoso, C. H. Simanjuntak, N. Punjabi, J. R. Campbell, W. K. Alexander, H. J. Beecham, A. L. Corwin, and B. A. Oyofo, Antimicrobial Resistance of Bacterial Pathogens Associated with Diarrheal Patients in Indonesia, American Journal of Tropical Medicine and Hygiene, 68: 666-670, (2003).

13. X. Zhao, and D. Drlica, Restricting the Selection of Antibiotic-Resistant Mutants: A General Strategy Derived from Fluoroquinolone Studies, Clinical Infectious Diseases, 33: S147-S156, (2001). 